\title{
Faktor-Faktor yang Mempengaruhi Perilaku Etis Mahasiwa Akuntansi
}

\author{
(Studi Pada Mahasiswa Akuntansi Perguruan Tinggi Swasta Di \\ Surakarta)
}

\author{
Fediana Asriani Sekartaji \\ Universitas Islam Batik (UNIBA) \\ Surakarta \\ fedianaasriani.s0297@gmail.com
}

\author{
Suhendro \\ Universitas Islam Batik (UNIBA) \\ Surakarta \\ dro_s@yahoo.com
}

\author{
Rosa Nikmatul Fajri \\ Universitas Islam Batik (UNIBA) Surakarta \\ rosanikmatulfajri@mail.ugm.ac.id
}

Corresponding Author: Fediana Asriani Sekartaji

Submitted: 10 Januari 2020

Accepted: 7 Juli 2020

Published: 1 Agustus 2020

\section{ABSTRACT}

This study aims to analyze the factors that influence ethical behavior of accounting students, including Intellectual Intelligence, Emotional Intelligence, Spiritual Intelligence, Understanding of the Accounting Code of Ethics, and Ethical Behavior. The population in this study is accounting students of private universities in Surakarta. The sampling technique uses purposive sampling, with the criteria of students who have taken auditing courses I and II, and obtained a sample of 100 respondents. This type of research is quantitative research. The type of data used is Primary data. The data analysis technique used is multiple linear regression analysis. The results showed that simultaneous intellectual intelligence, emotional intelligence, spiritual intelligence and understanding of accounting ethics influence the ethical behavior of accounting students. Partially shows that intellectual intelligence has no effect on the ethical behavior of accounting students, while emotional intelligence, spiritual intelligence, understanding of accounting ethical codes, affects the ethical behavior of accounting students. The benefits of this study are as a reference and reference for further research related to the ethical behavior of accounting students.

Keywords : Intellectual Intelligence, Emotional Intelligence, Spiritual Intelligence, Understanding of the Code of Ethics in Accounting, Sand Ethical Behavior

\section{PENDAHULUAN}

Semua profesi dituntut bekerja secara profesional. Kemampuan dan keahlian khusus yang dimiliki oleh suatu profesi adalah suatu keharusan agar profesi tersebut mampu bersaing di dunia usaha. Selain itu profesi harus memiliki etika yang diatur dan harus ditaati oleh pihakpihak yang menjalankan, Suatu profesi harus berperilaku etis sesuai dengan moral 
dan nilai-nilai yang berlaku. Kantor Akuntan Publik (KAP) ternama di Tanah Air, Tahun 2019 merupakan tahun yang cukup suram. Pasalnya, sudah ada beberapa temuan kasus tak terpuji yang dilakukan oleh KAP. Ada tiga KAP yang terkena kasus terkait laporan keuangan. Dua diantaranya bahkan terbukti melanggar Pasal 66 UUPM jis. paragraf A 14 SPAP SA 200 dan Seksi 130 Kode Etik Profesi Akuntan Publik-Institut Akuntan Publik dalam kasus penggelembungan pendapatan laoran keuangan PT Hanson international Tbk periode 2016. (CNN, 2019)

Ikatan Akuntan Indonesia (IAI) mengeluarkan suatu standar profesi yang memuat seperangkat prinsip-prinsip moral tentang perilaku profesional yaitu kode etik Akuntan Indonesia yang mengatur hubungan antara akuntan dengan para klien, antara akuntan dengan sejawatnya dan antara profesi dengan masyarakat. Ikatan Akuntan Indonesia (IAI) sebagai organisasi akuntan di Indonesia telah memiliki Kode Etik IAI yang merupakan amanah dari AD/ART IAI dan peraturan yang berlaku, yaitu Keputusan Menteri Keuangan No. 263/KMK.01/2014 tentang Penetapan Ikatan Akuntan Indonesia Sebagai Organisasi Profesi Akuntan (IAI, 2016). Dalam Kode Etik Akuntan Indonesia disebutkan bahwa tujuan profesi akuntansi adalah memenuhi tanggung jawabnya dengan standar profesionalisme tertinggi, dalam mencapai tingkat kinerja tertinggi dengan orientasi kepada kepentingan publik. Ikatan Akuntansi Indonesia telah berupaya untuk melakukan penegakan etika profesi bagi auditor. Oleh karena itu pemahaman setiap akuntan tentang kode etik profesi akuntansi yang berlaku di Indonesia dapat pula berbeda antara satu dengan yang lain. Prinsip etika profesi antara lain menyebutkan bahwa dengan menjadi anggota, seorang akuntan mempunyai kewajiban untuk menjaga disiplin diri diatas dan melebihi yang disyaratkan oleh hukum dan peraturan.

Berdasarkan penjelasan diatas maka Perilaku dari para pemimpin di masa depan dapat diprediksi dari perilaku mahasiswa sekarang. Perilaku mahasiswa perlu diteliti untuk mengetahui sejauh mana mereka akan bersikap etis atau tidak di masa yang akan datang. Masalah etika menjadi suatu isu yang penting dalam bidang akuntansi di perguruan tinggi, karena lingkungan pendidikan memiliki andil dalam membentuk perilaku mahasiswa untuk menjadi seorang yang profesional. Perguruan tinggi merupakan penghasil sumber daya manusia yang profesional, yang diharapkan dapat memenuhi kebutuhan pasar yang ada, oleh karena itu dituntut dapat menghasilkan tenaga profesional yang memiliki kualifikasi keahlian sesuai bidang ilmunya, dan juga memiliki perilaku etis yang tinggi (Wardana, A. Gede A. W; Mimba, N.P.S.H.M;, 2016)

Dalam berbagai penelitian menurut (Sutri, 2016) menunjukkan bahwa pengaruh kecerdasan intelektual, kecerdasan emosional dan kecerdasan spriritual secara simultan berpengaruh signifikansi terhadap perilaku etis mahasiswa akuntansi. Hasil penelitian tersebut berbeda dengan hasil penelitian yang dilakukan oleh Anis (Su'udiyah, Anis;, 2017) menunjukkan bahwa kecerdasan intelektual, kecerdasan emosional, dan kecerdasan spiritual secara simultan berpengaruh signifikan terhadap perilaku sikap etis mahasiswa akuntansi. Sedangkan secara parsial kecerdsan Intelektual berpengaruh positif terhadap perilaku sikap etis mahasiswa akuntansi, dan kecerdasan emosional dan kecerdasan spiritual tidak berpengaruh terhadap perilaku sikap etis mahasiswa akuntansi.

Hasil penelitian oleh (Wijayanti, Rita;, 2018) menunjukkan bahwa sifat machiavellian, kecerdasan spiritual, dan pemahaman terhadap kode etik profesi 
akuntan memiliki pengaruh positif dengan perilaku etis mahasiswa akuntansi, namun untuk variabel kecerdasan emosional tidak berpengaruh terhadap perilaku etis mahasiswa akuntansi. Beragamnya hasil penelitian tersebut menyebabkan penelitian ini dilakukan kembali untuk memperoleh bukti empiris. Perbedaan dalam penelitian ini yaitu dalam pengambilan sampel yaitu mahasiswa Akuntansi di Perguruan Tinggi di Surakarta dengan menggunakan metode kuantitatif dan menambahkan variabelnya yaitu Kesadaran Intelektual, Kesadaran Emosional, Kesadaran Spiritual, dan pemahaman kode etik profesi akuntansi. Penelitian akan dilakukan langsung oleh peneliti kepada mahasiswa sebagai narasumber, sehingga hasil penelitian ini dapat menggambarkan kondisi sebenarnya. Hasil penelitian ini diharapkan dapat menunjukkan apa saja faktor yang mempengaruhi perilaku etis mahasiswa akuntansi dalam melakukan sebuah profesi akuntansi. Dengan demikian peneliti mengusulkan judul "Faktor-faktor Yang Mempengaruhi Perilaku Etis Mahasiswa Akuntansi".

\section{LANDASAN TEORI}

\subsection{Teori Atribusi}

Teori atribusi menjelaskan bahwa tindakan yang dilakukan seseorang disebabkan karena atribut penyebab. Tindakan seorang pemimpin maupun orang yang diberi wewenang dipengaruhi oleh atribut penyebab. Teori atribusi mempelajari proses bagaimana seseorang mengintepretasikan suatu peristiwa, alasan, atau sebab perilakunya. Heider mengembangkan teori ini dengan memberikan argumentasi bahwa perilaku seseorang ditentukan oleh kombinasi antara kekuatan internal (internal forces) dan kekuatan eksternal (external forces). Kekuatan internal (internal forces) yaitu faktor-faktor yang berasal dari dalam diri seseorang/individu akan kemampuannya secara personal mampu memengaruhi kinerja serta perilakunya misalnya seperti sifat, karakter, sikap, kemampuan, keahlian maupun usaha. Kekuatan eksternal (external forces) yaitu faktorfaktor yang berasal dari luar kendali individu misalnya seperti tekanan situasi, kesulitan dalam pekerjaan atau keberuntungan (Bestari, D S; , Azlina; , Julita;, 2016).

\subsection{Kecerdasan Intelektual}

Kecerdasan intelektual berkaitan dengan keterampilan bicara, kecerdasan akan ruang, kesadaran akan sesuatu yg tampak, dan penguasaan matematika. Mengukur kecepatan kita untuk mempelajari hal-hal baru, memusatkan perhatian pada aneka tugas dan latihan, menyimpan dan mengingat kembali informasi objektif,terlibat dalam proses berfikir, bekerja dengan angka, berpikir abstrak dan analitis, serta memecahkan masalah dan menerapkan pengetahuan yg telah ada sebelumnya (Trihandandini, R.A Fabiola Meirnayati;, 2005).

\subsection{Kecerdasan Emosional}

Kecerdasan emosional adalah kemampuan seseorang untuk mengenali emosi pribadinya sehingga tahu kelebihan dan kekurangannya, kemampuan seseorang untuk mengelola emosi tersebut, kemampuan seseorang untuk memotivasi dan memberikan dorongan untuk maju kepada diri sendiri, kemampuan seseorang untuk mengenal emosi dan kepribadian orang lain, kemampuan seseorang untuk membina hubungan dengan pihak lain secara baik. Jika kita memang mampu memahami dan melaksanakan kelima wilayah utama kecerdasan emosi tersebut, maka semua perjalanan bisnis atau karier apapun yang kita lakukan akan lebih berpeluang berjalan mulus (Goleman D;, 2015).

\subsection{Kecerdasan Spiritual}

Kecerdasan spiritual adalah kecerdasan untuk menghadapi dan 
memecahkan persoalan makna dan nilai, yaitu menempatkan perilaku dan hidup manusia dalam konteks makna yang lebih luas dan kaya, serta menilai bahwa tindakan atau jalan hidup seseorang lebih bermakna dibandingkan dengan yang lain. Kecerdasan spiritual simbolkan sebagai teratai diri yang menggabungkan tiga kecerdasan dasar manusia (rasional, emosional dan spiritual), tiga pemikiran (seri, asosiatif dan penyatu), tiga jalan dasar pengetahuan (primer, sekunder, dan tersier) dan tiga tingkatan diri (pusattranspersonal,tengah-asositif \& interpersonal dan pinggiran-ego personal). Dengan demikian, kecerdasan spiritual berkaitan dengan unsur pusat dari bagian diri manusia yang paling dalam menjadi pemersatu seluruh bagian diri manusia lain (Bestari, D S; , Azlina; , Julita;, 2016).

\subsection{Pemahaman Kode Etik Akuntansi}

Kode etik profesi merupakan suatu tatanan etika yang telah disepakati oleh suatu kelompok masyarakat tertentu. Kode etik umumnya termasuk dalam norma sosial, namun bila ada kode etik yang memiliki sanksi yang agak berat, maka masuk dalam kategori norma hukum. Kode Etik juga dapat diartikan sebagai pola aturan, tata cara, tanda, pedoman etis dalam melakukan suatu kegiatan atau pekerjaan. Kode etik merupakan pola aturan atau tata cara sebagai pedoman berperilaku. Tujuan kode etik agar profesional memberikan jasa sebaik-baiknya kepada pemakai atau nasabahnya. Adanya kode etik akan melindungi perbuatan yang tidak profesional. "kode etik profesi merupakan norma yang telah ditetapkan dan di terima oleh kelompok profesi dan untuk mengarahkan atau memberikan petunjuk kepada para anggotanya, yaitu bagaimana "seharusnya" berbuat dan sekaligus menjamin kualitas moral profesi yang bersangkutan di mata masyarakat untuk memperoleh tanggapan yang positif" (Pamela, Astriana;, 2016).

\subsection{Perilaku Etis Mahasiwa Akuntansi}

Perilaku etis adalah perilaku yang beretika dalam organisasi untuk pelaksanakan tindakan secara adil sesuai hukum konstitusional dan peraturan pemerintah yang dapat diaplikasikan, Etis berarti yang sesuai dengan aturan atau standar atau praktik perilaku yang benar, khususnya standar profesi. Jadi, Perilaku etis adalah tindakan yang secara etis dapat membedakan mana yang benar dan salah sesuai dengan aturan-aturan moral yang berlaku. Perilaku etis merupakan perilaku yang sesuai dengan norma-norma sosial yang diterima secara umum berhubungan dengan tindakan-tindakan yang bermanfaat dan tidak membahayakan (Pamela, Astriana;, 2016)

\subsection{Penelitian Sebelumnya}

Penelitian oleh (Su'udiyah, Anis; 2017)yang berjudul kecerdasan intelektual, kecerdasan emosional dan kecerdasan spiritual terhadap sikap etis mahasiswa akuntansi.Hasil ini menunjukan bahwa pengaruh kecerdasan intelektual berpengaruh positif terhadap perilaku etis mahasiswa akuntansi sedangkan, kecerdasan emosional dan kecerdasan spiritual berpengaruh negatif terhadap perilaku etis mahasiswa akuntansi.

Penelitian oleh (Wijayanti, Rita;, 2018) yang berjudul Studi Determinasi perilaku etis mahasiswa akuntansi. Hasil ini menunjukan bahwa pengaruh sifat Machiavellian, kecerdasan emosinal, Kecerdasan Spiritual dan Pemahaman Kode Etik Profesi akuntansi berpengaruh positif terhadap perilaku etis mahasiswa akuntansi sedangkan kecerdasan emosional berpengaruh negatif terhadap perilaku etis mahasiswa akuntansi.

Penelitian oleh (Sutri, 2016) yang berjudul faktor-faktor yang mempengaruhi perilaku etis mahasiswa akuntansi. Hasil ini menunjukkan bahwa 
pengaruh kecerdasan intelektual, kecerdasan emosional dan kecerdasan spriritual berpengaruh positif terhadap perilaku etis mahasiswa akuntansi.

Penelitian oleh (Soedjatmiko; Abdullah, H; Nor, Asiah;, 2017) Yang berjudul Pengaruh Pemahamn Kode Etik Profesi Akuntansi Terhadap Perilaku Etis Mahasiswa menunjukkan bahwa pengaruh kode etik profesi akuntansi berpengaruh positif terhadap perilaku etis mahasiswa akuntansi.

\subsection{Kerangka Pemikiran}

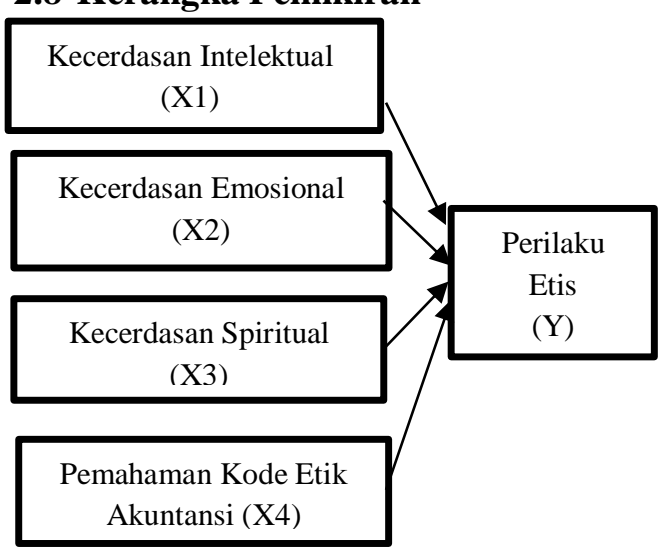

Gambar 1. Kerangka Pemikiran

\subsection{Hipotesis Penelitian}

\subsubsection{Pengaruh}

Kecerdasan Intelektual Terhadap Perilaku Etis Mahasiswa Akuntansi

Menurut penelitian dari (Wijayanti, Rita; 2018) menunjukan bahwa pengaruh sifat Machiavellian, berpengaruh terhadap perilaku etis mahasiswa. Hasil penelitian ini konsisten dengan penelitian dari (Sutri, 2016) menunjukkan bahwa pengaruh kecerdasan intelektual berpengaruh terhadap perilaku etis mahasiswa akuntansi.

H1: Kecerdasan Intelektual Terhadap Perilaku Etis Mahasiswa Akuntansi.

\subsubsection{Pengaruh}

Kecerdasan

Emosional Terhadap Perilaku Etis Mahasiswa Akuntansi

Menurut penelitian yang dilakukan oleh (Wijayanti, Rita;, 2018)
Menunjukan bahwa kecerdasan emosional berpengaruh negatif terhadap perilaku etis mahasiswa akuntansi. Hasil ini konsisten dengan penelitian oleh (Su'udiyah, Anis;, 2017). Menunjukkan bahwa kecerdasan emosional berpengaruh negatif terhadap perilaku etis mahasiswa akuntansi.

H2: Kecerdasan Emosional Terhadap Perilaku Etis Mahasiswa Akuntansi.

\subsubsection{Pengaruh Kecerdasan Spiritual Terhadap Perilaku Etis Mahasiswa Akuntansi}

Menurut penelitian yang dilakukan oleh (Wijayanti, Rita; 2018)menunjukkan bahwa kecerdasan spiritual berpengaruh negatif terhadap perilaku etis mahasiswa akuntansi. Hasil ini konsisten dengan penelitian (Sutri, 2016)menunjukkan bahwa kecerdasan spiritual berpengaruh negatif terhadap perilaku etis mahasiswa akuntansi.

H3: Kecerdasan Spiritual Terhadap Perilaku Etis Mahasiswa Akuntansi.

\subsubsection{Pengaruh Pemahaman Kode Etik Akuntansi terhadap Perilaku Etis Mahasiswa Akuntansi}

Menurut Penelitian yang dilakukan oleh (Soedjatmiko; Abdullah, $\mathrm{H}$; Nor, Asiah;, 2017) menunjukkan bahwa pengaruh kode etik profesi akuntansi berpengaruh positif terhadap perilaku etis mahasiswa akuntansi. Hasil ini konsisten dengan penelitian (Wijayanti, Rita;, 2018) menunjukkan bahwa pengaruh kode etik profesi akuntansi berpengaruh positif terhadap perilaku etis mahasiswa akuntansi.

H4: Pemahaman kode etik akuntansi terhadap perilaku etis mahasiwa akuntansi.

\section{METODE PENELITIAN}

Jenis penelitian ini menggunakan penelitian Kuantitatif. Sumber data menggunakan data primer, dengan instrumen penelitian berupa kuesioner dan wawancara. Populasinya adalah 
mahasiswa akuntansi perguruan tinggo swasta di surakarta. Berdasarkan teknik purposive sampling dimana kriteria yang harus dipenuhi yaitu mahasiswa yang sudah menempuh mata kuliah audit I dan II, diperoleh sampel sebanyak 100 responden. Teknik analisis data menggunakan analisis regresi linier berganda.

Tabel 1.Variabel Penelitian dan Pengukurannya

\begin{tabular}{lc}
\hline Skala Likert & $\begin{array}{c}\text { Point } \\
\text { Penilaian }\end{array}$ \\
\hline Sangat Setuju & 5 \\
Setuju & 4 \\
Cukup setuju & 3 \\
Tidak Setuju & 2 \\
$\begin{array}{l}\text { Sangat Tidak } \\
\text { Setuju }\end{array}$ & 1 \\
\hline \multicolumn{2}{l}{ Sumber : Penelitian Sebelumnya }
\end{tabular}

IV. HASIL DAN PEMBAHASAN

\subsection{Deskripsi Umum Data Penelitian}

Penelitian ini menggunakan data primer yang diperoleh dengan menyebar kuesioner kepada responden. Populasi dalam penelitian ini adalah mahasiswa akuntansi di Surakarta yang terdiri dari Universitas Islam Batik Surakarta, STIE Surakarta, STIE AAS, STIE Adi Unggul Bhirawa, dan STIE St. Pignatelli.

Tabel 2.Pendistribuasian Kuesioner

\begin{tabular}{lc}
\hline \multicolumn{1}{c}{ Keterangan } & Jumlah \\
\hline $\begin{array}{l}\text { Kuesioner yang } \\
\text { disebar }\end{array}$ & 120 \\
$\begin{array}{l}\text { Kuesioner yang } \\
\text { tidak kembali }\end{array}$ & 5 \\
$\begin{array}{l}\text { Kuesioner yang } \\
\text { tidak memenuhi }\end{array}$ & 15 \\
kriteria &
\end{tabular}

Kuesioner yang

100

kembali dan

dianalisis

Sumber : Data diolah (2019)

Berdasarkan tabel diatas, penelitian ini dilakukan mulai tanggal 09 Desember sampai 30 Desember 2019 dengan jumlah kuesioner yang disebarkan sebanyak 120 kuesioner dengan rincian seperti diatas.

\subsection{Hasil Penelitian \\ 4.2.1. Uji Instrumen}

4.2.1.1. Uji Validitas

Uji validitas item merupakan uji instrumen untuk mengukur apakah pertanyaan dalam kuesioner yang dibuat betul-betul dapat mengukur apa yang hendak diukur. Dalam penelitian ini teknik uji validitas item menggunakan metode korelasi perason, yaitu dengan cara mengorelasikan skor item dengan skortotalnya. Skor total adalah penjumlahan seluruh item pada satu variabel. Pengujian signifikan dilakukan dengan kriteria menggunakan $r$ tabel pada tingkat signifikansi 0,05 dengan uji 2 sisi. Apabila $\mathrm{r}$ hitung $>\mathrm{r}$ tabel maka pertanyaan dinyatakan valid.

\section{Tabel 2. Hasil Uji Validitas}

\begin{tabular}{cccc}
$\begin{array}{c}\text { Nomor } \\
\text { Pertanyaan }\end{array}$ & $\mathrm{r}_{\text {hitung }}$ & $\mathrm{r}_{\text {tabel }}$ & Keterangan \\
\hline 1 & 0,604 & 0,196 & Valid \\
2 & 0,54 & 0,196 & Valid \\
3 & 0,56 & 0,196 & Valid \\
4 & 0,496 & 0,196 & Valid \\
5 & 0,428 & 0,196 & Valid \\
6 & 0,61 & 0,196 & Valid \\
7 & 0,554 & 0,196 & Valid \\
8 & 0,652 & 0,196 & Valid \\
9 & 0,539 & 0,196 & Valid \\
10 & 0,608 & 0,196 & Valid \\
\hline \multicolumn{5}{l}{ Variabel Kecerdasan Intelektual } \\
\hline 1 & 0,655 & 0,196 & Valid
\end{tabular}




\begin{tabular}{|c|c|c|c|c|c|c|c|}
\hline 2 & 0,67 & 0,196 & Valid & 22 & 0.646 & 0,196 & Valid \\
\hline 3 & 0,763 & 0,196 & Valid & 23 & 0.691 & 0,196 & Valid \\
\hline 4 & 0,756 & 0,196 & Valid & 24 & 511 & 0,196 & Valid \\
\hline 5 & 0,727 & 0,196 & Valid & \multirow{2}{*}{\multicolumn{4}{|c|}{$\begin{array}{c}\text { Variabel Pemahaman Kode Etik } \\
\text { Akuntansi } \\
\end{array}$}} \\
\hline 6 & 0,688 & 0,196 & Valid & & & & \\
\hline 7 & 0,762 & 0,196 & Valid & 1 & 0,705 & 0,196 & Valid \\
\hline 8 & 0,77 & 0,196 & Valid & 2 & 0,633 & 0,196 & Valid \\
\hline 9 & 0,746 & 0,196 & Valid & 3 & 0,705 & 0,196 & Valid \\
\hline \multicolumn{4}{|c|}{ Variabel Kecerdasan Emosional } & 4 & 0,594 & 0,196 & Valid \\
\hline 1 & 0,537 & 0,196 & Valid & 5 & 0,538 & 0,196 & Valid \\
\hline 2 & 0,428 & 0,196 & Valid & 6 & 0,531 & 0,196 & Valid \\
\hline 3 & 0,638 & 0,196 & Valid & 7 & 0,63 & 0,196 & Valid \\
\hline 4 & 0,682 & 0,196 & Valid & 8 & 0,742 & 0,196 & Valid \\
\hline 5 & 0,544 & 0,196 & Valid & \multirow{2}{*}{\multicolumn{4}{|c|}{$\begin{array}{c}\text { Variabel Perilaku Etis Mahasiswa } \\
\text { Akuntansi } \\
\end{array}$}} \\
\hline 6 & 0,71 & 0,196 & Valid & & & & \\
\hline 7 & 0,64 & 0,196 & Valid & \multirow{3}{*}{\multicolumn{4}{|c|}{$\begin{array}{l}\text { Sumber : Data diolah (2019) } \\
\text { 4.2.2. Uji Reliabilitas } \\
\text { Uji Reliabilitas digunakan untuk } \\
\text { mengetahui nilai reliabilitas penelitian }\end{array}$}} \\
\hline 8 & 0,717 & 0,196 & Valid & & & & \\
\hline \multicolumn{4}{|c|}{ Variabel kecerdasan spiritual } & & & & \\
\hline 1 & 0,727 & 0,196 & Valid & \multirow{10}{*}{\multicolumn{4}{|c|}{$\begin{array}{l}\text { menggunakan tehnik Crobach Alpha } \\
\text { yang terdapat pada program SPSS } 22 \text { For } \\
\text { Windows. Hasil penelitian reliabilitas } \\
\text { dalam penelitian ini adalah sebagai } \\
\text { berikut: maka dapat dikemukakan hasil uji } \\
\text { reliabilias diatas dengan Crobach's Alpha } \\
\text { pada setiap pertanyaan bernilai positif dan } \\
\text { menunjukan nilai } \mathrm{r}_{\text {alpha }}>\mathrm{r}_{\text {kritis }} \text { sehingga } \\
\text { dapat disimpulkan bahwa seluruh item } \\
\text { pertanyaan variabel pemahaman kode etik } \\
\text { akuntansi dalam instrumen penelitian ini } \\
\text { adalah reliabel. }\end{array}$}} \\
\hline 2 & 0,627 & 0,196 & Valid & & & & \\
\hline 3 & 0,725 & 0,196 & Valid & & & & \\
\hline 4 & 0,631 & 0,196 & Valid & & & & \\
\hline 5 & 0,687 & 0,196 & Valid & & & & \\
\hline 6 & 0,684 & 0,196 & Valid & & & & \\
\hline 7 & 0,683 & 0,196 & Valid & & & & \\
\hline 8 & 0,72 & 0,196 & Valid & & & & \\
\hline 9 & 0.723 & 0,196 & Valid & & & & \\
\hline 10 & 0.622 & 0,196 & Valid & & & & \\
\hline 11 & 0.673 & 0,196 & Valid & \multirow{2}{*}{\multicolumn{4}{|c|}{$\begin{array}{c}\text { Tabel } 4 . \\
\text { Hasil Uji Reliabilitas } \\
\end{array}$}} \\
\hline 12 & 0.686 & 0,196 & Valid & & & & \\
\hline 13 & 0.697 & 0,196 & Valid & \multirow{3}{*}{$\begin{array}{l}\text { Nomor } \\
\text { Pertanyaan }\end{array}$} & \multirow{3}{*}{$\mathrm{r}_{\text {alpha }}$} & \multirow{3}{*}{$\mathrm{r}_{\text {kritis }}$} & \multirow{3}{*}{ Keterangan } \\
\hline 14 & 0.721 & 0,196 & Valid & & & & \\
\hline 15 & 0.673 & 0,196 & Valid & & & & \\
\hline 16 & 0.591 & 0,196 & Valid & 1 & 0,709 & 0,6 & Reliabel \\
\hline 17 & 0.691 & 0,196 & Valid & 2 & 0,718 & 0,6 & Reliabel \\
\hline 18 & 0.691 & 0,196 & Valid & 3 & 0,735 & 0,6 & Reliabel \\
\hline 19 & 0.748 & 0,196 & Valid & 4 & 0,725 & 0,6 & Reliabel \\
\hline 20 & 0.558 & 0,196 & Valid & 5 & 0,747 & 0,6 & Reliabel \\
\hline 21 & 0.613 & 0,196 & Valid & 6 & 0,708 & 0,6 & Reliabel \\
\hline
\end{tabular}




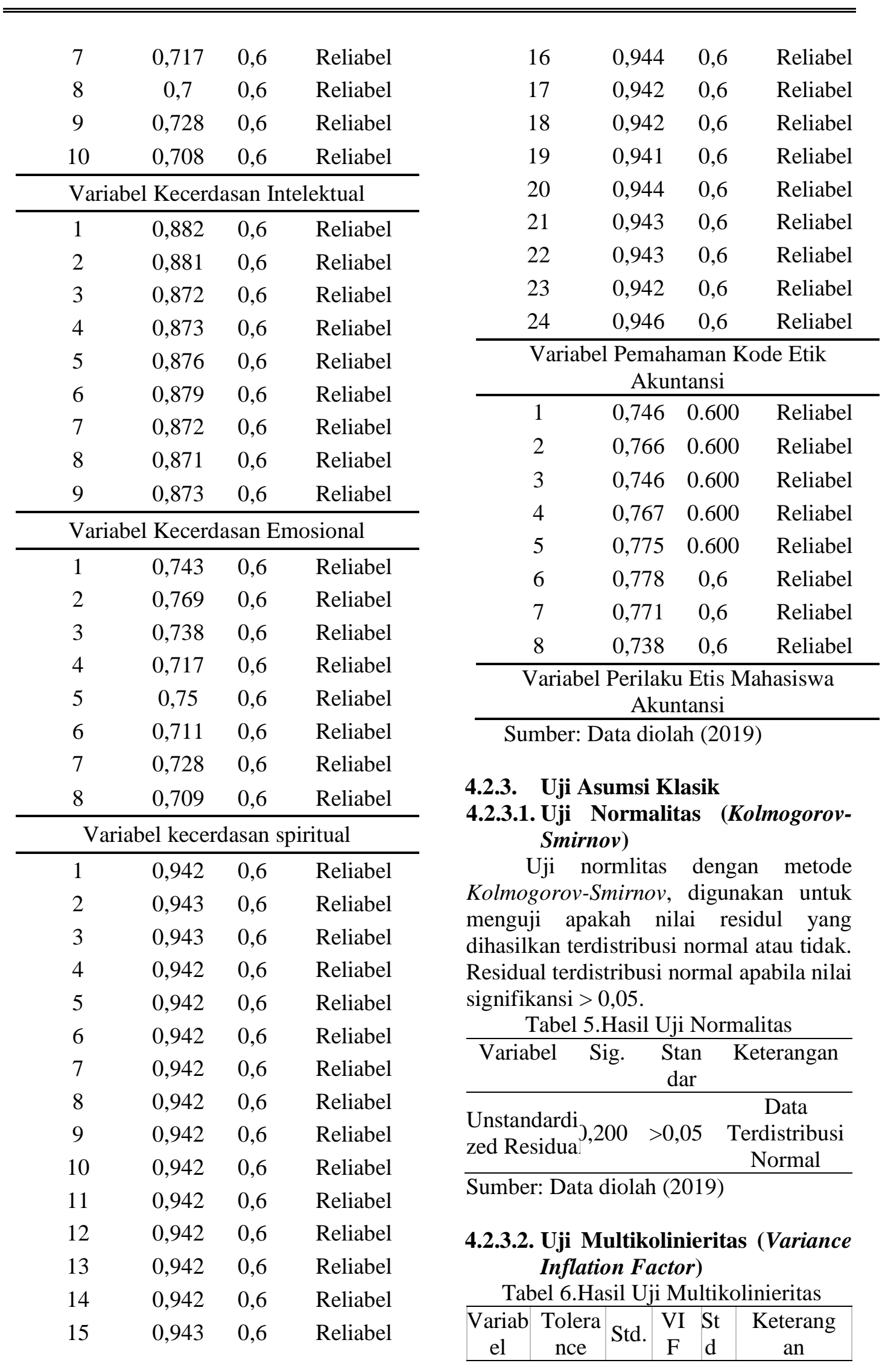




\begin{tabular}{|c|c|c|c|c|c|}
\hline KI & 0,571 & $\begin{array}{c}<0,1 \\
0\end{array}$ & $\begin{array}{l}17 \\
50\end{array}$ & $\begin{array}{c}<1 \\
0\end{array}$ & $\begin{array}{c}\text { Tidak } \\
\text { terjadi } \\
\text { multikoli } \\
\text { nearitas }\end{array}$ \\
\hline $\mathrm{KE}$ & 0,208 & $\begin{array}{c}>0,1 \\
0\end{array}$ & $\begin{array}{l}9.2 \\
65\end{array}$ & $\begin{array}{l}<1 \\
0\end{array}$ & $\begin{array}{c}\text { Tidak } \\
\text { terjadi } \\
\text { multikoli } \\
\text { nearitas }\end{array}$ \\
\hline $\mathrm{KS}$ & 0,627 & $\begin{array}{c}>0,1 \\
0\end{array}$ & $\begin{array}{l}1.5 \\
94\end{array}$ & $\begin{array}{l}<1 \\
0\end{array}$ & $\begin{array}{c}\text { Tidak } \\
\text { terjadi } \\
\text { multikoli } \\
\text { nearitas }\end{array}$ \\
\hline PKEA & 0,101 & $\begin{array}{c}>0,1 \\
0\end{array}$ & $\begin{array}{l}9.9 \\
36\end{array}$ & $\begin{array}{l}<1 \\
0\end{array}$ & $\begin{array}{c}\text { Tidak } \\
\text { terjadi } \\
\text { multikoli } \\
\text { nearitas }\end{array}$ \\
\hline
\end{tabular}

Sumber: Data diolah (2019)

Dari tabel 4, diketahui nilai Tolerance $>0,10$ dan nilai VIF $<10$, maka dapat dinyatakan bahwa tidak terjadi multikolinieritas.

\subsubsection{Uji Autokorelasi Watson)}

(Durbin

Tabel 7. Hasil Uji Autokorelasi

\begin{tabular}{cccccc}
\hline DW & $\mathrm{dU}$ & $\mathrm{Dl}$ & 4-dU & 4-dL & Keterangan \\
\hline & & & & & Tidak \\
2.05 & 1.592 & 1.758 & 2.40 & 2.824 & Terjadi \\
7 & 2 & 2 & 78 & 18 & $\begin{array}{c}\text { Autokorela } \\
\text { si }\end{array}$ \\
\hline
\end{tabular}

Sumber: Data diolah (2019)

Dari tabel 5, dapat diketahui nilai Durbin Watson sebesar 2.057 yang terletak diantara dU dan 4-dU $(1.5922<2,057<2, .4078) . \quad$ Maka disimpulkan bahwa tidak terjadi autokorelasi.

\subsubsection{Uji Heteroskedastisitas \\ (Spearman's rho)}

Tabel 8.Hasil Uji Heteroskedastisitas

\begin{tabular}{cccc}
\hline Variabel & $\begin{array}{c}\text { Sig. } \\
(2- \\
\text { tailed })\end{array}$ & Standar & Keterangan \\
\hline KI & 0.696 & 0,05 & $\begin{array}{c}\text { Tidak Terjadi } \\
\text { Heteroskedastisitas }\end{array}$
\end{tabular}

\begin{tabular}{|c|c|c|c|}
\hline KE & 0.454 & 0.05 & Tidak Terjadi \\
\hline & & & Heteroskedastisitas \\
\hline KS & 0.810 & 0.05 & $\begin{array}{c}\text { Tidak Terjadi } \\
\text { Heteroskedastisitas }\end{array}$ \\
\hline PKEA & 0.378 & 0.05 & $\begin{array}{c}\text { Tidak Terjadi } \\
\text { Heteroskedastisitas }\end{array}$ \\
\hline
\end{tabular}

Sumber: Data diolah (2019)

Pengujian heteroskedastisitas menggunakan metode Spearman's rho. Dari tabel 6 diketahui nilai Sig. (2-tailed) masing-masing variabel $>0,05$. Maka dapat disimpulkan bahwa tidak terjadi heteroskedastisitas.

\subsubsection{Uji Regresi Linier Berganda}

\subsubsection{Model Regresi}

Tabel 9.Model Regresi

\begin{tabular}{lc}
\hline \multicolumn{1}{r}{ Model } & $\mathrm{B}$ \\
\hline (Constant) & 11.392 \\
KI & -0.010 \\
KE & -0.506 \\
KS & 0.234 \\
PKEA & 0.342 \\
\hline
\end{tabular}

Sumber: Data diolah (2019)

$$
\begin{aligned}
\mathrm{Y}= & 11.392+(-0.010)_{\mathrm{KI}}+(-0.506)_{\mathrm{KE}}+ \\
& 0.234_{\mathrm{KS}}+0.342_{\mathrm{PKEA}}
\end{aligned}
$$

Persamaan diatas dapat dijelaskan sebagai berikut:

1) Nilai konstanta adalah 11.392,artinya jika kecerdasan intelektual, kecerdasan emosional,kecerdasan spiritual dan pemaham kode etik akuntansi bernilai 0 ,maka perilaku etis akan bernilai tetap 11.392.

2) Nilai koefisien regresi variabel kecerdasan intelektual bernilai negatif, yaitu -0.010,artinya setiap penurunan kecerdasan intelektual sebesar satu persen (1\%) maka perilaku etis akan menurun sebesar -0.010 .

3) Nilai koefisien regresi variabel kecerdasan spiritual bernilai positif, yaitu 0.234 , artinya setiap peningkatan kecerdasan spiritual sebesar satu persen $(1 \%)$ maka perilaku etis akan meningkat sebesar 0.234 
4) Nilai koefisien regresi variabel struktur modal sebesar 1,579, dapat diartikan bahwa setiap peningkatan struktur modal sebesar 1 persen maka akan meningkatkan nilai perusahaan sebesar 1,579 dengan asumsi variabel lain tetap.

5) Nilai koefisien regresi variabel pemahaman kode etik akuntansi bernilai positif, yaitu 0.342 , artinya setiap peningkatan pemahaman kode etik akuntansi sebesar satu persen $(1 \%)$ maka perilaku etis akan meningkat sebesar 0.342 .

4.2.4.2. Uji Kelayakan Model

Tabel 10.Hasil Uji F-Statistik

\begin{tabular}{|c|c|c|}
\hline $\begin{array}{c}\text { Keterang } \\
\mathrm{n}\end{array}$ & $\mathrm{F}_{\text {hitung }} \mathrm{F}_{\text {tabel }}$ & $\begin{array}{c}\text { Sig }_{\text {hitu }} \text { ng Sig. Hasil } \\
\end{array}$ \\
\hline \multirow{2}{*}{ Uji F } & $12.79>2.7$ & $0,000<0,0$ Model \\
\hline & $9 \quad 00$ & $0,000 \quad 5$ Layak \\
\hline
\end{tabular}

Sumber: Data diolah (2019)

Dari tabel 8, dapat diketahui $F_{\text {hitung }}$ $>\mathrm{F}_{\text {tabel }}(12.799>2.700)$ dan Signifikansi $<0,05(0,000<0,05)$, maka Ho ditolak. Sehingga dapat disimpulkan bahwa kecerdasan intelektual, kecerdasan emosional, kecesdasan spiritual dan pemahaman kode etik akuntansi secara simultan mempengaruhi perilaku etis mahasiswa akuntansi.

\subsubsection{Uji Hipotesis (Uji t)}

Tabel 10.Hasil Uji Hipotesis

\begin{tabular}{|c|c|c|c|c|c|}
\hline $\begin{array}{c}\text { Hipotes } \\
\text { is }\end{array}$ & $t_{\text {hitung }}$ & $t_{\text {tabel }}$ & Sig. & Std. & $\begin{array}{c}\text { Keteran } \\
\text { gan }\end{array}$ \\
\hline H1 & 0.110 & 1.985 & $\begin{array}{l}0,9 \\
13\end{array}$ & $\begin{array}{c}<0,0 \\
5\end{array}$ & $\begin{array}{c}\text { Diterim } \\
\mathrm{a}\end{array}$ \\
\hline $\mathrm{H} 2$ & $2.390^{-}$ & $\begin{array}{c}1.98 \\
5\end{array}$ & $\begin{array}{r}0,0 \\
19\end{array}$ & $\begin{array}{c}<0,0 \\
5\end{array}$ & Ditolak \\
\hline H3 & 2.019 & $\begin{array}{c}1.98 \\
5\end{array}$ & $\begin{array}{r}0,0 \\
46\end{array}$ & $\begin{array}{c}<0,0 \\
5\end{array}$ & $\begin{array}{c}\text { Diterim } \\
\mathrm{a}\end{array}$ \\
\hline H4 & 3.852 & $\begin{array}{c}1.98 \\
5\end{array}$ & $\begin{array}{r}0,0 \\
00\end{array}$ & $\begin{array}{c}<0,0 \\
5\end{array}$ & Ditolak \\
\hline
\end{tabular}

Berdasarkan tabel 9, jika nilai thitung $>t_{\text {tabel }}$ dan Signifikansi $<0,05$, maka dapat disimpulkan bahwa variabel independen secara parsial berpengaruh terhadap variabel dependen.

\subsubsection{Uji Koefisien Determinasi $\left(\mathbf{R}^{\mathbf{2}}\right)$}

Tabel 12.Hasil Uji Koefisien Determinasi $\left(\mathrm{R}^{2}\right)$

\begin{tabular}{ccc}
\hline Model & $\begin{array}{c}\text { Adjusted R } \\
\text { Square }\end{array}$ & Keterangan \\
\hline 1 & 0,323 & $\begin{array}{c}\text { Berpengaruh } \\
32.3 \%\end{array}$ \\
\hline
\end{tabular}

Sumber: Data diolah (2019)

Dari tabel 10 diatas, diketahui nilai Adjusted R Square sebesar 0,323. Artinya pengaruh variabel kecerdasan intelektual, kecerdasan emosional, kecerdasan spiritual dan pemahaman kode etik akuntansi terhadap perilaku etis mahasiswa akuntansi sebesar 32.3\%, sedangkan sisanya $67.7 \%$ dipengaruhi oleh variabel lain yang tidak dimasukkan dalam penelitian ini.

\subsection{Pembahasan}

Berdasarkan hasil pengujian pada tabel 11, dapat disimpulkan bahwa hipotesis pertama, menyatakan bahwa pengujian kecerdasan intelektual tidak berpengaruh terhadap perilaku etis yang dilakukan oleh mahasiswa akuntansi. Berdasarkan hasil uji $t$, nilai $t_{\text {hitung }}$ dari hipotesis 1 adalah 0.110 dan $t_{\text {tabel }}$ sebesar 1.985. karena nilai nilai $t_{\text {hitung }}<t_{\text {tabel }}$ (0.110<1.985), maka hasil $\mathrm{H}_{1}$ ditolak. Dengan demikian dapat disimpulkan bahwa kecerdasan intelektual tidak berpengaruh terhadap perilaku etis yang dilakukan oleh mahasiswa akuntansi.

Kecerdasan intelektual merupakan kemampuan menganalisis, logika dan rasio seseorang. Dalam penelitian ini kecerdasan intelektual tidak berpengaruh terhadap perilaku etis yang dilakukan oleh mahasiswa akuntansi karena kecerdasan intelektual harus mampu untuk dapat mengerti dan peka terhadap persoalan etika, yang sangat dipengaruhi oleh lingkungan dia berada. Hal ini tidak sejalan dengan penelitian (Sutri, 2016) 
yang menyatakan bahwa kecerdasan intelektual berpengaruh terhadap perilaku etis yang dilakukan oleh mahasiswa akuntansi

Hipotesis kedua menyatakan bahwa pengujian kecerdasan emosional berpengaruh terhadap perilaku etis yang dilakukan oleh mahasiswa akuntansi. Berdasarkan hasil uji $t$, nilai $t_{\text {hitung }}$ dari hipotesis 1 adalah -2.390 dan $\mathrm{t}_{\text {tabel }}$ sebesar 1.985. karena nilai nilai $t_{\text {hitung }}<\mathrm{t}_{\text {tabel }} \quad(-$ $2.390<-1.985$ ), maka hasil $\mathrm{H}_{2}$ ditolak. Dengan demikian dapat disimpulkan bahwa kecerdasan intelektual tidak berpengaruh terhadap perilaku etis yang dilakukan oleh mahasiswa akuntansi. Kecerdasan emosional adalah kemampuan untuk mengenali perasaan diri sendiri dan perasaan orang lain, memotivasi diri sendiri, serta mengelola emosi dengan baik pada diri sendiri dan dalam hubungan dengan orang lain (Goleman D;, 2015). Dalam penelitian ini kecerdasan emosional berpengaruh terhadap perilaku etis yang dilakukan oleh mahasiswa. Hal ini disebabkan oleh mahasiswa akuntansi dapat melakukan pengendalian diri seperti mengelola dan mengendalikan emosi, menerima saran dan kritik, peka terhadap sekitar dan suka mencoba hal-hal baru. Hal ini sejalan dengan penelitian (Handayani; , Hidayat, 2010) menyatakan bahwa kecerdasan emosional berpengaruh terhadap perilaku etis yang dilakukan oleh mahasiswa akuntansi.

Hipotesis ketiga menyatakan bahwa pengujian kecerdasan emosional berpengaruh terhadap perilaku etis yang dilakukan oleh mahasiswa akuntansi. Berdasarkan hasil uji $t$, nilai $t_{\text {hitung }}$ dari hipotesis 1 adalah 2.019 dan $t_{\text {tabel }}$ sebesar 1.985. karena nilai nilai $t_{\text {hitung }}<\mathrm{t}_{\text {tabel }} \quad(2019$ < 1.985), maka hasil $\mathrm{H}_{3}$ ditolak. Dengan demikian dapat disimpulkan bahwa kecerdasan intelektual tidak berpengaruh terhadap perilaku etis yang dilakukan oleh mahasiswa. Kecerdasan spiritual adalah kecerdasan untuk menghadapi dan memecahkan persoalan makna dan nilai. Dalam penelitian ini kecerdasan spiritual berpengaruh terhadap perilaku etis yang dilakukan oleh mahasiswa. Hal ini disebabkan oleh mahasiswa akuntansi mampu dan memiliki bersikap fleksibel seperti spontan dan mudah menerima pendapat orang lain secara terbuka; mahasiswa juga memiliki kesadaran diri seperti menyadari diri sendiri dan berdoa sebelum melakukan sesuatu. Hal ini sejalan dengan penelitian (Handayani; , Hidayat, 2010) menyatakan bahwa kecerdasan spiritual berpengaruh terhadap perilaku etis yang dilakukan oleh mahasiswa akuntansi.

Hipotesis keempat menyatakan bahwa pengujian pemahamn kode etik akuntansi berpengaruh terhadap perilaku etis yang dilakukan oleh mahasiswa akuntansi. Berdasarkan hasil uji t, nilai $\mathrm{t}_{\text {hitung }}$ dari hipotesis 1 adalah 3.852 dan $\mathrm{t}_{\text {tabel }}$ sebesar 1.985. karena nilai nilai $\mathrm{t}_{\text {hitung }}<\mathrm{t}_{\text {tabel }}$ (3.852<-1.985), maka hasil $\mathrm{H}_{4}$ ditolak. Dengan demikian dapat disimpulkan bahwa kecerdasan intelektual tidak berpengaruh terhadap perilaku etis yang dilakukan oleh mahasiswa akuntansi. Kode etik profesi merupakan suatu tatanan etika yang telah disepakati oleh suatu kelompok masyarakat tertentu . Dalam penelitian ini pemahaman kode etik akuntansi berpengaruh terhadap perilaku etis yang dilakukan oleh mahasiswa. Hal ini disebabkan bahwa individu yang memiliki pemahamn yang baik akan dapat memahamihal-hal yang boled dan tidak dilakukan oleh seorang profesi. Hal ini sejalan dengan penelitian (Safiraa;, 2016), menyatakan bahwa pemahaman kode etik akuntansi berpengaruh terhadap perilaku etis yang dilakukan oleh mahasiswa akuntansi.

Hipotesis kelima membuktikan bahwa bahwa mahasiswa akuntansi perempuian lebih berperilaku etis dibandikan mahasiswa akuntansi lakilaki. Hal ini berarti bahwa apabila 
mahasiswa akuntansi tersebut perempuan akan meningkatkan perilaku etis mahasiswa akuntansi.

\section{KESIMPULAN DAN SARAN}

Berdasarkan hasil penelitian dan pembahasan yang telah dikemukakan diatas, maka dapat disimpulkan bahwa: (1) secara parsial kebijakan kecerdasan emosional, kecerdasan spiritual dan pemahaman kode etik akuntansi berpengaruh terhadap perilaku etis mahasiswa akuntansi, sedangkan kecerdasan intelektual tidak berpengaruh terhadap perilaku etis mahasiswa akntansi, (2) secara simultan kecerdasan intelektual, kecerdasan emosional, kecerdasan spiritual dan pemahaman kode etik akuntansi berpengaruh terhadap perilaku etis mahasiswa akuntansi, (3) pengaruh variabel kecerdasan intelektual, kecerdasan emosional, kecerdasan spiritual dan pemahaman kode etik akuntansi terhadap perilaku etis mahasiswa akuntansi sebesar $32.3 \%$, sedangkan sisanya $67.7 \%$ dipengaruhi oleh variabel lain yang tidak dimasukkan dalam penelitian ini.

Keterbatasan dalam penelitian ini antara lain: 1) Penelitian ini hanya menggunakan 5 perguruan tinggi swasta di Surakarta, dikarenakan dalam penyebaran kuesioner terhambat dengan libur hari natal dan tahun baru. 2) Variabel yang digunakan hanya menggunakan variabel Kecerdasan intelektual, kecerdasan emosional, kecerdasan spiritual dan pemahaman kode etik akuntansi. Sedangkan masih ada variabel lain yang dapat mempengaruhi perilaku kecurangan akademik. 3)Terbatasnya sampel dalam penelitian ini pada mahasiswa akuntansi, sehingga hasil penelitian tidak dapat digeneralisasi.

Saran bagi penelitian selanjutnya yaitu diharapkan dapat : 1) Bagi peneliti selanjutnya diharapkan dapat menggunakan atau mengikutsertakan semua perguruan tinggi swasta di
Surakarta. 2) Bagi peneliti selanjutnya dapat menambahkan variabel lain selain yang dapat mempengaruhi kecurangan akademik. 3) Bagi peneliti selanjutnya dapat menambahkan sampel dalam penelitian agar hasil penelitian dapat digeneralisasikan. 4) Perlu dilakukan penelitian mendalam dengan menggunakan instrument penelitian dengan memperbanyak item-item pertanyaan.

\section{DAFTAR PUSTAKA}

Anwar S. (2012). Pengantar Pgsikologi Intelegensi. Yogyakarta: Pustaka Pelajar.

Bestari, D S; , Azlina; , Julita;. (2016). Pengaruh Keefektifan

Pengendalian Internal, Asimetri Informasi dan Moralitas Individu Terhadap Kecenderungan Kecurangan Akuntansi dengan Perilaku Tidak Etis Sebagai Variabel Intervening. JOM Fekon, 3, 1436-1447.

Dewi, Tiara Kusuma; Wirakusuma, Made Gede;. (2018). Pengaruh Kecerdasan Intelektual, Kecerdasan Emosional, dan Kecerdasan Spiritual pada Perilaku Etis Dengan Pengalaman Sebagai Variabel Pemoderator. $E$ Jurnal Ekonomi dan Bisnis Universitas Udayana, 20912115.

Fachmi, A. H. N; Utami, S. D. M;. (2017). Etika Profesi Akuntansi Dan Permasalahan Audit. In Prosiding Seminar Nasional dan Call For Paper Ekonomi dan Bisnis, 2728. 
Goleman D;. (t.thn.). Kecerdasan Emosi Untuk Mencapai Puncak Prestasi. Dalam Working With Emotional Intelligence (A. T. Widodo, Penerj., Ke Enam .). Jakarta: PT Gramedia Pustaka.

Handayani; , Hidayat. (2010). Peran Faktor-Faktor Individual dan Pertimbangan Etis Terhadap Perilaku Auditor Dalam Situasi Konflik Audit pada Lingkungan Inspektorat Sulawesi Tenggara. Jurnal Mitra Ekonomi Dan Manajemen Bisnis, 1(1), 83-112.

Hutahahean, M. Umar Bakri; , Hasnawati. (2015). Pengaruh Gender, Religiusitas dan Prestasi Belajar Terhadap Perilaku Etis Akuntan Masa Depan (Studi Pada Mahasiswa Akuntansi Perguruan Tinggi Swasta Di Wilayah DKI Jakarta). e-Journal Akuntansi Trisakti, 2(1), 49-66.

M, R. T. (2012). Kecerdasan Intelektual. Jurnal Ekonomi dan Bisnis Manajemen, 3.

Martadi; , Indiana Farid; , Suranta Sri;. (2016). Persepsi Akuntan, Mahasiswa Akuntansi, dan Karyawan Bagian Akuntansi Dipandang dari Segi Gender Terhadap Etika Bisnis dan Etika Profesi. Simposium Nasional Akuntansi 9 Padang.

Mulyadi;. (2001). Sistem Akuntansi. Dalam Buku I Edisi Ke Enam. Jakarta, Jakarta: PT. Salemba Empat.
Mulyadi; $\quad$ (2002). Auditing (Pengauditan). PT. Salemba Empat.

Obasi, Rosemary O.; Ekatah, Rosemasy Uagbule;. (2016). Demographic Indicators and Professional Ethical Behaviour of Accounting Students. IOSR Journal of Business and Management (IOSR-JBM), 18(7), 12-18.

Oktarina, Ridha; , Sany DWita; , Halmawati;. (2017). Pengaruh Gender Terhadap Perilaku Etis Akuntan Di Minangkabau (Studi Eksperimentasi Semu pada Mahasiswa Akuntansi di Kota Padang). Jurnal WRA, 5(1).

Pamela, Astriana;. (2016). Pengaruh Pemahaman Kode etik akuntansi terhadap perilaku etis Pada mahasiswa akuntansi Universitas negri yogyakarta.

Rini, R; Damiati, L;. (2017). Analisis Hasil Audit Pemerintahan Dan Tingkat Korupsi Pemerintahan Provinsi Di Indonesia. Jurnal Dinamika Akuntansi Dan Bisnis, 4(1), 73.

Soedjatmiko; Abdullah, H; Nor, Asiah;. (2017). Pengaruh Pemahamn Kode Etik Profesi Akuntansi Terhadap Perilaku Etis Mahasiswa STIE Nasional Banjamasin. DINAMIKA EKONOMI Jurnal Ekonomi dan Bisnis, 10(2), 18-35.

Sugiyono. (2007, 2007). Statistika Untuk Penelitian. 
Sugiyono;. (2009). Metode Penelitian Bisnis. Bandung.

Sutri, H. (2016, September). Faktor-faktor yang mempengaruhi perilaku etis mahasiswa akuntansi universitas islam lamongan. Jurnal EKBIS, $X V I(2), 809-817$.

Su'udiyah, Anis;. (2017). pengaruh kecerdasan

intelektual,kecerdasan emosional, dan kecerdasan spiritual secara simultan berpengaruh signifikan terhadap sikap etis mahasiswa akuntansi. XI, 18-24.

Syukriyah Agustini; Adiputra, I Made Pradana;. (2013). Effect of intellectual intelligence, emotional intelligence and spiritual intelligence ethical attitudes of accounting students s1 education university of ganesha singaraa. International conference on enterpreneurship and business management (ICEBM) 2013(ISBN : 978-9799234-49-0), 21-22.

Trihandandini, R.A Fabiola Meirnayati;. (2005). Analisis Pengaruh Kecerdasa Intelektual, Kecerdasan Emosi dan Kecerdasan Spiritual terhadap Kinerja Karyawan. Tesis.

Wardana, A. Gede A. W; Mimba, N.P.S.H.M;. (2016). Pengaruh Kecerdasan Intelektual, Kecerdasan Emosional, Kecerdasan Spiritual, dan Gender pada Sikap Etis Mahasiswa Magister Akuntansi Universitas Udayanan. E-Jurnal Ekonomi
Dan Bisnis Universitas Udayana, 5(10), 3501-3530.

Widiyanto I;. (2008). Pointers Metode Penelitian.

Wijayanti, Rita;. (2018). Studi Determinan Perilaku Etis Mahasiswa Akuntansi. 14, 142156.

Zohar, D; Marshall, I;. (2002). SQ:Memanfaatkan SQ dalam Berpikir Holistik untuk Memaknai Kehidupan. Dalam Mizan (Penyunt.), SQ:Spiritual Intelligence-The Ultimate Intelligence (Astuti, N. B. Ahmad, \& B. Ahmad, Penerj., Cetakan Kelima ed.). Bandung. 